\title{
Kajian Potensi Pendidikan Formal Animasi di Sekolah Menengah Kejuruan Kota Cimahi 2011
}

\author{
Mohammad Rizaldi ${ }^{1}$, Intan R. Mutiaz ${ }^{2} \&$ Iman Sujudi ${ }^{2}$ \\ ${ }^{1}$ Program Magister Desain, Fakultas Seni Rupa dan Desain, Institut Teknologi Bandung, \\ Jalan Ganesa No. 10, Bandung 40132, Indonesia \\ ${ }^{2}$ Program Studi Desain Komunikasi Visual, Fakultas Seni Rupa dan Desain, Institut \\ Teknologi Bandung, Jalan Ganesa No. 10, Bandung 40132, Indonesia \\ Email: intanrm@yahoo.com
}

\begin{abstract}
Abstrak. Penjabaran PP No.28 tahun 2008 terkait Kebijakan Industri Nasional (KIN) menetapkan kota Cimahi sebagai basis kota pengembangan industri animasi dan mengambil leading sector di bidang animasi, film dan ICT. Dalam bidang animasi, potensi SDM animasi SMK dinilai oleh pakar dan industri cukup diminati namun kurang dari sisi kompetensi dan kualitas hasil. Penelitian ini akan mengungkap eksistensi edukasi animasi tingkat SMK di Cimahi berdasarkan parameter kualitas hasil tes gambar sketsa presentasi siswa animasi untuk dikaitkan pada evaluasi edukasi animasi SMK di Cimahi. Penelitian ini menunjukkan kurangnya kemampuan menggambar siswa sebagai kemampuan dasar animasi. Berdasarkan hal tersebut, dirumuskan suatu strategi peningkatan potensi edukasi formal SDM animasi SMK di kota Cimahi dengan menggunakan saringan ujian masuk gambar secara tepat yang sesuai dengan karakteristik keahlian bidang animasi.
\end{abstract}

Kata Kunci: animasi; evaluasi; gambar; kejuruan; strategi.

Abstract. Explanation of PP No.28 of 2008 related to the National Industrial Policy (KIN) sets Cimahi city as a base of animation industry development and as a leading sector in the field of animation, film and ICT. Vocational high school animation rated by industry experts is quite attractive but less in terms of competence and result qualities. This study reveal the lack of competence of animation education at vocational high school level in Cimahi based on quality parameters of the drawing test from students sketch presentations. Therefore, to improve its potentials, a formulated education strategy and student entry test based on drawing is needed followed with refining other educational process.

Keywords: animation; drawing; evaluation; strategy; vocational school.

\section{$1 \quad$ Pendahuluan}

Sekretaris Jenderal Departemen Perindustrian Agus Tjahajana mengemukakan dalam acara pemaparan kinerja industri tahun 2008, bahwa industri kreatif informasi dan komunikasi telah ditetapkan sebagai industri prioritas, khususnya

Received September $3^{\text {rd }} 2012$, Revised September $27^{\text {th }}, 2013$, Accepted November $29^{\text {th }}, 2013$

Copyright () 2013 Published by LPPM ITB, ISSN: 1978-3078, DOI: 10.5614/itbj.vad.2013.5.2.1 
industri animasi. Kota Cimahi yang saat ini menjadi basis pengembangan industri animasi terkait dengan penjabaran dari PP No. 28 Tahun 2008 mengenai Kebijakan Industri Nasional (KIN) [1] bekerja sama dengan Cimahi Creative Association (CCA), berusaha untuk memancing minat para animator dan pelaku animasi baik amatir ataupun profesional, perorangan maupun studio dalam berbagai lomba dan workshop berupa training animasi tingkat SMASMK dan umum. Banyaknya partispasi dan keterlibatan SDM SMK dalam berbagai acara yang terkait animasi di Cimahi tersebut menandakan bahwa mereka memiliki potensi yang besar untuk menggerakkan roda perekonomian Cimahi melalui animasi.

Potensi tersebut masih dipertanyakan karena walaupun kualitas keluaran hasil animasi tersebut dinilai cukup bagus dalam hasil beberapa lomba animasi Cimahi dan memiliki alumni SMK (SMKN 1) yang sangat aktif di lingkup Cimahi menurut data komunitas CCA, 2011, namun kurang berani bersaing di pasar nasional maupun internasional. Hal tersebut terlihat dari minimnya keikutsertaan animasi SMK Cimahi di kancah nasional maupun internasional.

Untuk merunut potensi dalam edukasi formal, maka disusunlah penelitian ini sebagai studi evaluasi kompetensi SDM animasi tingkat SMK di Cimahi. Hasilnya selain untuk meningkatkan mutu edukasi animasi SMK di Cimahi, juga diharapkan dapat mempertegas posisi edukasi animasi tingkat SMK dalam mencapai keunggulan kompetensi animasinya pada jenjang pendidikan nasional berdasarkan kebutuhan industri animasi.

Berdasarkan premis tersebut maka disusunlah formulasi permasalahan berikut: Bagaimana strategi optimalisasi edukasi animasi formal yang dapat diterapkan pada tingkat SMK di Kota Cimahi?

\section{Metode}

Metode analisis data yang akan digunakan adalah analisis data induktif dengan metoda penelitian kausal komparatif untuk menyelidiki sebab yang mungkin untuk suatu pola yang dilakukan dengan cara membandingkan subyek dimana pola tersebut ada dengan subyek yang serupa dimana pola tersebut tidak ada atau berbeda. Tujuan utamanya adalah untuk menyelidiki apakah satu atau lebih kondisi yang sudah terjadi mungkin menyebabkan perbedaan perilaku pada subyek. Metode tersebut diawali oleh analisis hasil tes gambar sebagai parameter kualitas eksisting edukasi animasi di SMK Cimahi yang dikomparasikan dengan SMK animasi berprestasi di Malang. 


\subsection{Pendekatan}

Penelitian ini akan menggunakan pendekatan studi kasus dimana secara sengaja mengambil SMK yang memiliki kurikulum animasi di Cimahi, yaitu SMKN 1 yang mengajarkan animasi sebagai muatan lokal di jurusan RPL dan TP4, lalu SMK-TI Garuda Nusantara Cimahi yang merupakan satu-satunya SMK yang memiliki jurusan animasi di Cimahi. Sebagai komparasinya diambil SMKN 4 Malang yang dikenal berprestasi di bidang animasi, lebih dari 30 prestasi dalam animasi semenjak berdiri pada 2007 (data internal jurusan animasi SMKN 4 Malang).

Pengukuran eksisting kualitas edukasi animasi akan didasarkan pada penilaian tes gambar sketsa presentasi, karena menurut mayoritas praktisi dan pelaku industri animasi pada acara sharing animasi di BITC Cimahi Juli 2011, kemampuan menggambar merupakan dasar kemampuan animasi yang mutlak dikuasai sebagai kemampuan berbahasa visual. Selain itu juga dikarenakan pada 2011, belum terdapat alumnus jurusan animasi pada SMK-TI Garuda Nusantara (berdiri tahun 2009) dan pada SMKN 1 Cimahi materi animasi masih merupakan muatan lokal pada jurusan teknik non animasi TP4 (Teknik Produksi dan Penyiaran Program Pertelevisian) sehingga dikhawatirkan bias dengan nilai kompetensi induknya.

Sesuai dengan metode kausal komparatif yang merupakan suatu bentuk penelitian kualitatif, maka analisis data berdasarkan instrumen tes yang dilakukan juga menggunakan teknik analisis kualitatif. Penilaian hasil tes gambar yang berupa angka sebagai indikatonya, kemudian dikonversi menjadi predikat hasil akhir yang mewakili angka-angka di setiap kategori tersebut.

\section{Hasil dan Pembahasan}

\subsection{Tinjauan}

Kelompok produktif dalam kelompok mata pelajaran di SMK terdiri atas sejumlah mata pelajaran yang diatur dan dikelompokkan dalam Dasar Kompetensi Kejuruan yang merupakan kekhususan dari SMK dimana kelompok produktif tersebut memerlukan juga pengajar-pengajar yang memiliki pengalaman di bidang industri terkait karena Kurikulum Tingkat Satuan Pendidikan (KTSP SMK) mengacu kepada Standar Kompetensi Kerja Nasional Indonesia (SKKNI). Hingga 2011, di program keahlian animasi belum ada yang mengacu pada SKKNI, hal tersebut dikarenakan belum terbentuknya SKKNI bidang keahlian animasi yang resmi di Indonesia sehingga digunakan Standar Kompetensi Nasional Bidang Keahlian Animasi (SKNBK Animasi) yang rancangannya telah disusun pada 2006 oleh pakar dan pelaku industri animasi [2]. 
Makna kompetensi merujuk pada Mendiknas (SK.04/U/2002) adalah seperangkat tindakan cerdas, penuh tanggung jawab yang dimiliki oleh seseorang sebagai syarat untuk dianggap mampu oleh masyarakat dalam melaksanakan tugas-tugas dibidang tertentu [3]. Sedangkan standar kompetensi kelulusan pada satuan pendidikan menengah kejuruan bertujuan untuk meningkatkan kecerdasan, pengetahuan, kepribadian, ahklak mulia, serta keterampilan untuk hidup mandiri dan mengikuti pendidikan lebih lanjut sesuai dengan kejuruannya [4]. Oleh karena itu dapat dirumuskan bahwa kompetensi SMK yang diharapkan dari program keahlian animasi adalah membentuk animator yang cerdas, mampu mengelola dan melaksanakan keahlian yang sesuai dengan industri terkait serta memiliki tanggung jawab sebagai bagian dari industri animasi nasional dan sebagai bagian dari masyarakat umum.

Animasi sendiri di SMK terutama di Cimahi banyak ditemui sebagai mata pelajaran Muatan Lokal (mulok) dari program keahlian Rekayasa Perangkat Lunak (RPL), Teknik Produksi dan Penyiaran Program Pertelevisian (TP4), Multimedia (MM) dan Desain Komunikasi Visual (DKV). Kurikulum Muatan Lokal menurut Undang-Undang no.20 tahun 2004 pasal 37 ayat (1) wajib dimiliki oleh pendidikan dasar dan menengah. Menurut panduan penyusunan KTSP jenjang Pendidikan Dasar dan Menengah [5] Muatan Lokal dijabarkan sebagai kegiatan kurikuler untuk mengembangkan kompetensi yang disesuaikan dengan ciri khas dan potensi daerah, yang materinya tidak dapat dikelompokkan dalam mata pelajaran yang ada, atau materinya terlalu banyak sehingga harus menjadi mata pelajaran tersendiri. Substansi mata pelajaran muatan lokal ditentukan oleh satuan pendidikan, tidak terbatas pada mata pelajaran keterampilan [6].

Karena Cimahi sendiri difokuskan pada pengembangan animasi sebagai potensi daerah, maka langkah untuk menjadikan animasi sebagai mata pelajaran muatan lokal pada program keahlian yang masih terkait dengan animasi sudah tepat. Kompetensi keahlian animasi sendiri pada SMK saat ini digolongkan pada bidang studi Teknologi Informasi dan Komunikasi dalam program studi keahlian Teknik Komputer dan Informatika, hal ini banyak menjadi pertanyaan dari guru dan pengajar animasi yang beropini bahwa animasi lebih dekat pada bidang studi seni rupa. Hal tersebut dikarenakan kompetensi animasi lebih banyak menggunakan kemampuan seni untuk mengekspresikan nalar, gerakan, gambar, dan sense animasi. Sebagai penegasan hal tersebut, Standar Kompetensi Nasional Bidang Keahlian Animasi [2] mencantumkan mengenai pentingnya keahlian kesenirupaan berupa kemampuan menggambar sebagai dasar pengembangan keahlian kompetensi animasi.

Dalam gambar sketsa, terutama sketsa presentasi, penambahan detail dapat menjadi poin unggulan, namun sebelum menyeketsa gambar, terlebih dahulu 
harus mengerti dan memahami koridor konteks dan batasan sejauh mana sketsa tersebut dapat dikembangkan, karena jika keluar dari batasan dan konteks, suatu gambar atau sketsa dapat menurun nilainya, atau bahkan bisa menjadi sebuah kesalahan yang fatal [7].

Prinsip, ekspresi, dan teknik menggambar, di atas tersebut merupakan dasar yang harus diperhatikan untuk membuat gambar yang 'bagus' dan 'benar', sedangkan untuk menghasilkan sebuah gambar yang menonjol diperlukan penambahan unsur kreativitas. Kreativitas dalam wujud gambar sendiri menurut hasil diskusi dan wawancara dengan Muhammad Ihsan (Program Studi Desain Produk Industri, FSRD, Institut Teknologi Bandung, September 2011) pakar bahasa rupa dari desain produk ITB, dapat dicirikan dari beberapa faktor yang mempengaruhi sebagai berikut dimana urutan teratas menjadi faktor yang terpenting (Gambar 1):

1. Kontekstual, dimana kreativitas yang memiliki nilai adalah yang dikembangkan sesuai dengan konteks dan lingkupnya.

2. Bermain dengan batasan, bercirikan proses kreasi yang bermain pada batas konteks.

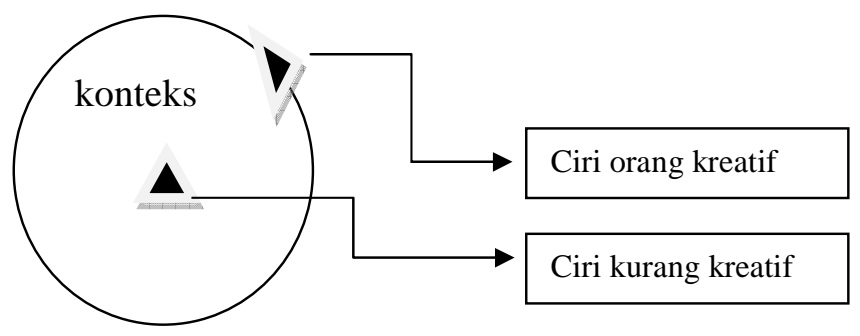

Gambar 1 Ciri Orang Kreatif: Bermain Dengan Batasan.

3. Original, dalam pengertian yang berbeda dari umum dan kebanyakan, 'nakal' mampu memunculkan nilai-nilai baru dan mengarah ke proses inovatif.

4. Wawasan, yang bercirikan nilai pengetahuan yang didasarkan oleh latar sosial budaya, pengalaman, kemampuan pengamatan, dan pengetahuan literatur.

5. Keberanian, yang berupa aksi untuk mengeksekusi ide dalam media gambar.

Penyederhanaan hal di atas dapat diuraikan melalui Tabel 1 di bawah ini yang memuat ciri-ciri yang terlihat dalam gambar: 
Tabel 1 Ciri-ciri yang terlihat pada gambar.

\begin{tabular}{ll}
\hline \multicolumn{1}{c}{ Unsur Gambar } & \multicolumn{1}{c}{ Ciri yang Terlihat } \\
\hline Kreativitas & 1. Kontekstual \\
& 2. Bermain dengan batasan \\
3. Original (berbeda dengan umum-inovatif) & 4. Wawasan (citra pengetahuan) \\
5. Keberanian & 1. Gaya, style, dan ciri khas gambar \\
(Fitness) & 2. Perwujudan elemen ekspresi didalam gambar berupa \\
& ekspresi wajah, gesture, tarikan garis, suasana. \\
Teknik & 1. Keluwesan penggunaan alat gambar \\
(Correctness) & 2. Pemaksimalan media gambar \\
& 3. Teknik rendering (arsir, shading) \\
4. Penguasaan menggambar obyek (karakter, benda komplek, still life) & 5. Penerapan prinsip gambar: \\
& * Kesatuan (harmoni dan keutuhan gambar) \\
& * Tekanan (penentuan obyek utama) \\
& * Keseimbangan (perbandingan jarak dan ukuran antar obyek) \\
& * Proporsi (perbandingan gambar dan media gambar) \\
& * Kesan 3 dimensi (penguasaan cahaya dan bayangan) \\
& * Elemen penunjang ( adanya faktor pembanding atau skala) \\
\hline
\end{tabular}

Ciri-ciri di atas didasari oleh proses dan tingkatan daya imajinasi yang berbedabeda pada tiap individu sehingga pola masukan yang sama dari stimuli luar dapat memunculkan keluaran hasil gambar yang berbeda-beda pada masingmasing individu. Dalam prosesnya, pemunculan ciri-ciri kreativitas dalam proses kreasi di atas berlangsung secara serempak dengan proses belajar, membentuk memori, dan berimajinasi, yang mana hal ini menurut Primadi sebagai pakar Bahasa Rupa, disebut dengan berpikir-integral, yaitu suatu kemampuan yang secara alamiah dimiliki oleh setiap manusia [8].

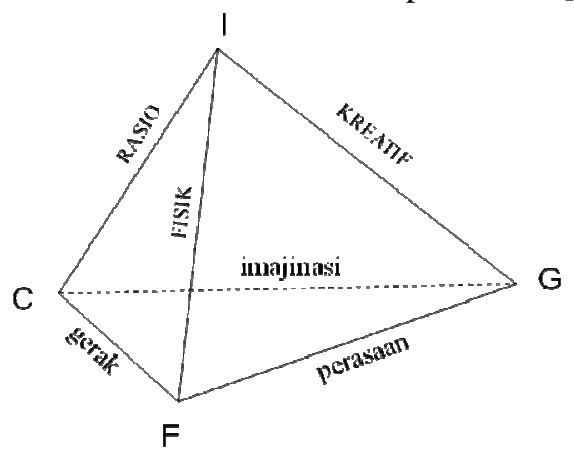

Gambar 2 Limas Citra Manusia oleh Primadi dalam Proses Kreasi, Apresiasi, Belajar [8]. 
Lebih lanjut menurut Primadi, kreativitas merupakan salah satu dari 3 kemampuan utama yang dimiliki oleh setiap manusia, yaitu fisik, rasio, dan kreatif. Kadar dari 3 kemampuan inilah yang berbeda-beda perimbangannya pada setiap manusia, hubungan ketiga kemampuan utama tersebut dilukiskan dalam bentuk limas yang disebut limas citra manusia [8] seperti pada Gambar 2.

Dalam limas tersebut dapat dilihat bahwa ketiga kemampuan utama manusia terletak pada rusuk utama, sedangkan pada alasnya terdiri dari gerak, perasaan, dan imajinasi. Garis yang saling berhubungan tersebut menggambarkan suatu proses kerjasama, misalnya kreativitas pada limas di atas, merupakan kerjasama dari kemampuan rasio dan imajinasi, serta juga merupakan kerjasama dari fisik dan perasaan.

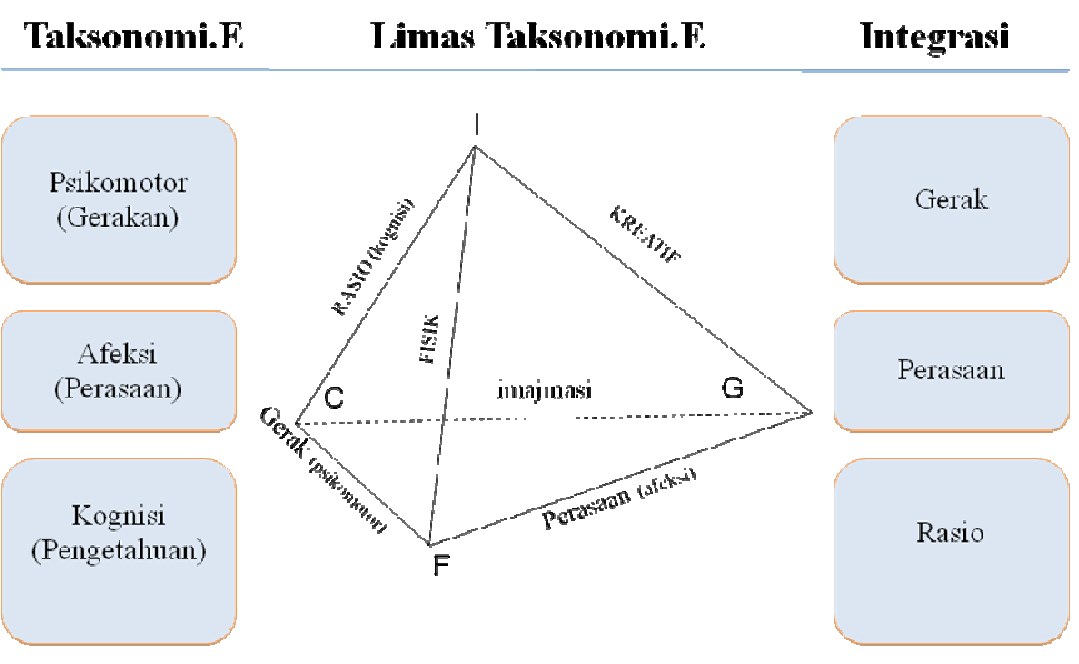

Gambar 3 Integrasi pada limas citra manusia berdasarkan parameter gambar menjadi limas taksonomi edukasi.

Di puncak limas terdapat intuisi (I) sebagai integrasi ketiga rusuk utama, lalu di ketiga ujung alas terdapat goodness $(\mathrm{G})$ yang merupakan integrasi antara kreatif, imajinasi, dan perasaan, lalu correctness (C) yang merupakan integrasi rasio, gerak, dan imajinasi, dan fitness (F) yang merupakan integrasi dari fisik, gerak, dan perasaan [8]. Goodness dalam unsur gambar dapat merupakan hasil output dari kreativitas, correctness dapat berarti benar secara teknik dan prinsip menggambar, serta fitness yang bisa berupa aktualisasi dan citra diri dari perasaan penggambar yang ekspresif.

Tiga kategori unsur yaitu kreativitas, ekspresi, dan teknik dipergunakan sebagai faktor penilaian utama terhadap analisis instrumen tes gambar dimana rata-rata 
dari ketiga unsur itulah yang akan menjadi nilai utama dalam sebuah gambar tersebut. Teori limas citra manusia dan taksonomi edukasi Bloom akan dileburkan dengan unsur-unsur dalam gambar tersebut untuk memperoleh koneksi dan keterkaitan antara ciri-ciri yang terlihat dalam gambar sebagai hasil analisis gambar tersebut dengan ranah edukasi dari taksonomi Bloom [9] yang mencakup kognisi, afeksi, dan psikomotor serta hubungannya dengan kemampuan siswa yang terlihat dalam limas citra manusia tersebut. Hasil leburan tersebut dapat disebut limas taksonomi edukasi.

Dalam Gambar 3 terlihat kedinamisan hubungan antara kemampuan utama manusia dengan nilai taksonomi edukasi. Jika dilihat pada proses kreatif dalam limas di atas maka kreativitas dapat dikatakan kerjasama dari kemampuan fisik dan ranah afeksi, juga merupakan kerjasama dari ranah kognisi dengan kemampuan imajinasi. Limas pada Gambar 3 dapat mencapai fungsinya apabila ranah rasio (pengetahuan) atau informasi diberikan dan diterima secara benar dan jelas, serta kondisi kemampuan fisik yang fit dan sehat serta memungkinkan untuk berkarya. Faktor imajinasi dalam limas tersebut dianggap kondisi yang khas dan ideal fungsinya pada setiap individu.

\subsection{Jenis Peserta dan Prosedur Tes}

Peserta tes diambil secara sengaja dan heterogen. Seluruh SMK yang mengambil mata pelajaran animasi rata-rata mengajarkan dasar gambar pada semester ganjil, oleh karena itu tes gambar dilakukan pada akhir semester genap. Tes SMKN 1 dilakukan pada siswa tingkat 2 jurusan Teknik Penyiaran dan Program Pertelevisian (TP4) sejumlah 27 siswa, hal tersebut dikarenakan edukasi animasi baru diajarkan di tingkat 2. Tes SMK-TI Garuda Nusantara dilakukan pada tingkat 1 sebanyak 24 siswa dan tingkat 2 sebanyak 8 siswa, belum ada siswa yang berada di tingkat 3 . Tes SMKN 4 Malang dilakukan pada 17 siswa tingkat 2 dan 3 secara acak. Jumlah peserta tertera pada Tabel 2.

Tabel 2 Tabel Jumlah Peserta Tes Gambar.

\begin{tabular}{lccc}
\hline & $\begin{array}{c}\text { Siswa Laki- } \\
\text { Laki }\end{array}$ & $\begin{array}{c}\text { Siswa } \\
\text { Perempuan }\end{array}$ & $\begin{array}{c}\text { TOTAL } \\
\text { PESERTA }\end{array}$ \\
\hline SMKN 1 Cimahi & 9 & 18 & 27 \\
SMK-TI GNC & 28 & 4 & 32 \\
SMKN 4 Malang & 5 & 12 & 17 \\
\hline TOTAL PESERTA & 42 & 34 & 76 \\
\hline PROSENTASE & $55,3 \%$ & $44,7 \%$ & $100 \%$ \\
\hline
\end{tabular}

Prosedur tesnya, siswa dikumpulkan dalam sebuah ruangan di masing-masing SMK tempat penyelenggaraan tes, setelah dilakukan pengenalan, siswa diberikan dua lembar kertas. Lembar pertama berisi identitas siswa dan lembar 
ke-2 berisi soal dan digunakan untuk media gambar. Petunjuk teknis yang diberikan adalah sebagai berikut:

1. Menggambar 9 obyek yang tertulis pada sebuah bidang kotak

2. (awan, gunung, matahari, ular, pohon, rumah, sungai, jembatan, dan ular).

3. Alat gambar yang digunakan bebas.

4. Tujuan dan bentuk gambar adalah sketsa presentasi

5. Menuliskan obyek yang paling disukai dibagian bawah.

6. Boleh menggunakan segala cara untuk menggambar.

7. Waktu menggambar 15 menit.

\subsection{Prosedur Penilaian Tes}

Hasil dari tes gambar akan dianalisis secara kualitatif melalui penilaian dengan angka berdasarkan tiga kategori, yaitu kreativitas, ekspresi, dan teknik yang mengacu pada Tabel 1. Tiap kategori memiliki rentang nilai 1 hingga 10 dimana angka 1 adalah paling buruk, dan angka 10 paling bagus, hasil dari ketiga kategori tadi lalu dirata-rata dan diberi label predikat [10] yang mewakili pembulatan angka yang dihasilkan.

Tabel 3 Tabel Nilai dan Predikat yang Mewakili.

\begin{tabular}{llllll}
\hline Predikat & $\begin{array}{l}\text { Kurang } \\
\text { Sekali }\end{array}$ & Kurang & Sedang & Baik & $\begin{array}{l}\text { Baik } \\
\text { Sekali }\end{array}$ \\
\hline Nilai & $1-2$ & $3-4$ & $5-6$ & $7-8$ & $9-10$ \\
\hline
\end{tabular}

Untuk mengejar hasil yang obyektif, maka selain peneliti, terdapat 2 orang penilai lain yang berasal dari latar keahlian animasi dan komik yang berasal dari asosiasi kreatif di Cimahi (CCA) dan masing-masing telah terjun secara profesional dibidang tersebut sehingga tim penilai terdiri dari 3 orang.

Sebelum proses penilaian, dijabarkan terlebih dahulu kondisi, peraturan, dan konteks yang melingkupi penyelenggaraan tes, serta mengenai unsur-unsur dalam gambar dan ciri-ciri yang terlihat terhadap unsur kreativitas, ekspresi, dan teknik sesuai dengan Tabel 1 yang bertujuan untuk menyamakan persepsi.

Untuk mengejar keobyektifan penilaian, tim penilai diberikan selembar kertas yang berisi garis penilaian polos sepanjang $10 \mathrm{~cm}$ yang mewakili angka 1-10, semakin kekanan torehan maka semakin baik nilainya. Penilaian dilakukan dengan cara mengukur posisi torehan dengan penggaris lalu hasilnya diubah menjadi angka sesuai perbandingan panjang garis nilai, setelah itu angka tersebut dirata-rata dengan pembulatan angka lalu diubah lagi ke predikat yang mewakili angka tersebut sesuai dengan Tabel 3. Contoh dari form hasil penilaian tes siswa terlihat seperti dalam Tabel 4 dibawah ini. 
Tabel 4 Contoh form penilaian hasil tes siswa laki-laki di SMK-TI Garuda Nusantara Cimahi.

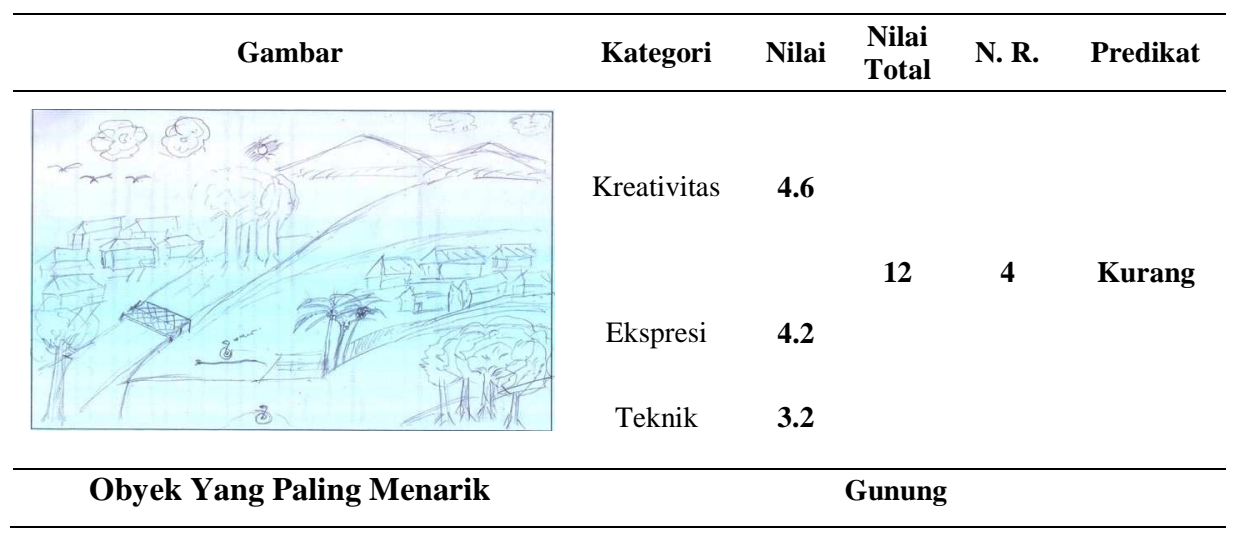

\subsection{Hasil}

Tabel 5 Komparasi kategori dan rata-rata hasil predikat tes SMK studi kasus di Cimahi dengan SMKN 4 di Malang.

\begin{tabular}{lccc}
\hline & SMKN 1 Cimahi & SMK-TI GNC & SMKN 4 Malang \\
\hline KATEGORI & PREDIKAT & PREDIKAT & PREDIKAT \\
\hline KREATIVITAS & Sedang & Sedang & Sedang \\
EKSPRESI & Kurang & Kurang & Sedang \\
TEKNIK & Kurang & Sedang & Baik \\
RATA-RATA & KURANG & SEDANG & BAIK \\
\hline
\end{tabular}

Jika diperhatikan dalam Tabel 5 di atas, terlihat bahwa predikat rata-rata pada SMKN 1 Cimahi dan SMK-TI Garuda Nusantara Cimahi masih pada level 'kurang' dan 'sedang', hal ini berbeda dengan hasil tes di SMKN 4 Malang yang mayoritas siswanya mendapat predikat 'baik'.

\subsubsection{Analisis Hasil Tes SMK TI Garuda Nusantara Cimahi}

Berikut ini pelibatan teori limas taksonomi edukasi mengenai penjabaran kemampuan utama manusia yang dikaitkan dengan ranah taksonomi edukasi sebagai saran evaluasi didasarkan pada Tabel 6.

Menurut tabel predikat terhadap unsur gambar diatas yang diterapkan pada limas taksonomi pendidikan pada Gambar 4, maka dapat dilihat kaitan predikat terhadap unsur gambar adalah sebagai berikut: 
1. Goodness (baik) dapat tercapai dengan meningkatkan kemampuan kreatifitas, dan melatih ranah afeksi yang masih terlihat kurang agar dapat terintegrasi baik dengan kemampuan imajinasi.

2. Corectness (benar) bisa tercapai dengan meningkatkan ranah psikomotorik.

3. Fitness (serasi) dapat tercapai dengan meningkatkan ranah psikomotorik dan terutama memperbaiki kekurangan pada ranah afeksi.

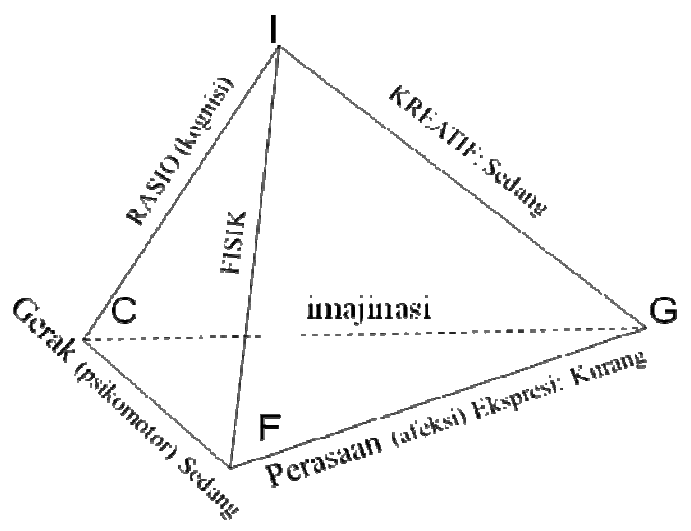

Gambar 4 Limas taksonomi edukasi terkait hasil tes SMK-TI Garuda Nusantara Cimahi.

Berdasarkan dari analisis di atas, maka yang perlu diperhatikan dalam kemampuan gambar sebagai dasar kemampuan animasi di SMK-TI Garuda Nusantara Cimahi adalah materi yang mencakup dan berhubungan terutama pada ranah afeksi.

\section{Pembahasan}

\subsection{Strategi Portal Kreatif Sebagai Basis Awal Seleksi Kompetensi Siswa Animasi SMK}

Gambar sebagai dasar kemampuan awal seorang pelaku animasi merupakan kunci kompetensi yang diakui oleh standar kompetensi nasional, juga oleh dunia industri, oleh karena itu diperlukan strategi yang menjadikan kemampuan menggambar sebagai dasar unsur kreativitas, unsur ekspresi diri, dan unsur teknik yang terukur sehingga dapat menjadi sebuah portal khusus berupa tes ujian masuk atau tes sertifikasi profesi dalam dunia pendidikan animasi maupun dunia animasi profesional. 
Strategi portal mengacu kepada makna portal yang dalam kamus bahasa Indonesia diartikan sebagai pintu gerbang. Penerapan strategi portal tersebut dalam pendidikan SMK animasi adalah sebagai gerbang pendidikan formal animasi dimana selain berfungsi sebagai standarisasi ujian saringan masuk (USM) SMK animasi, juga dapat digunakan sebagai langkah awal monitoring potensi dan kompetensi siswa yang mengikuti tes tersebut. Strategi portal tersebut dapat disusun berdasarkan elemen dan unsur-unsur berupa ciri-ciri yang terlihat pada sebuah gambar, seperti tertera pada Tabel 6 berikut:

Tabel 6 Pengembangan strategi portal siswa animasi SMK.

\begin{tabular}{|c|c|c|}
\hline Unsur Gambar & Ciri yang Terlihat & Strategi Portal \\
\hline $\begin{array}{l}\text { Kreativitas } \\
(\text { Goodness })\end{array}$ & $\begin{array}{l}\text { 1. Kontekstual } \\
\text { 2. Bermain dengan batasan } \\
\text { 3. Original (berbeda dengan umum- } \\
\text { inovatif) } \\
\text { 4. Wawasan (citra pengetahuan) } \\
\text { 5. Keberanian }\end{array}$ & $\begin{array}{l}\text { Portal Kreativitas } \\
\text { - Tes Gambar Konsep } \\
\text { - Tes Kreativitas dan problem } \\
\text { solver } \\
\text { - Tes Psikologi-Spatial } \\
\text { - Tes Potensi Akademik }\end{array}$ \\
\hline $\begin{array}{l}\text { Ekspresi } \\
\text { (Fitness) }\end{array}$ & $\begin{array}{l}\text { 1. Gaya, style, dan ciri khas gambar } \\
\text { 2. Perwujudan elemen ekspresi } \\
\text { didalam gambar berupa ekspresi } \\
\text { wajah, gesture, tarikan garis, } \\
\text { suasana. }\end{array}$ & $\begin{array}{l}\text { Portal Aktualisasi nilai } \\
\text { Ekspresif } \\
\text { - Tes Gambar Presentasi } \\
\text { - Tes Psikologi Assesment - } \\
\text { Menjual gambar } \\
\text { - Tes Gambar Bebas }\end{array}$ \\
\hline $\begin{array}{l}\text { Teknik } \\
\text { (Correctness) }\end{array}$ & $\begin{array}{l}\text { 1. Keluwesan penggunaan alat gambar } \\
\text { 2. Pemaksimalan media gambar } \\
\text { 3. Teknik rendering (arsir, shading) } \\
\text { 4. Penguasaan menggambar obyek } \\
\text { (karakter, benda komplek, still life) } \\
\text { 5. Penerapan prinsip gambar }\end{array}$ & $\begin{array}{l}\text { Portal Keahlian Terencana } \\
\text { - Tes Gambar Komposisi } \\
\text { - Tes Efisiensi Waktu Gambar } \\
\text { - Tes Rendering Gambar } \\
\text { Manual } \\
\text { (Arsir, shading) }\end{array}$ \\
\hline
\end{tabular}

Tabel di atas menampilkan beberapa arah pengembangan strategi portal yang cocok dan dapat diterapkan sesuai dengan strategi kompetensi yang dicari dan diinginkan terhadap siswa SMK animasi. Dalam perkembangannya, strategi portal ini dapat dikembangkan sesuai dengan tuntutan kompetensi SDM dan jenis lembaga penyelenggara terkait animasi. Strategi portal tersebut akan berjalan dengan baik dan bermanfaat jika diikuti dengan rekomendasi kegiatan akademik yang mengikutinya, seperti dijelaskan pada Tabel 7.

Selain pengadaan portal sebagai seleksi masuk, untuk mengoptimalkan kompetensi didalam proses penyelenggaraan akademiknya, dibutuhkan pula perangkat berupa pengajar dan sarana prasarana pendukung yang kondusif. 
Tabel 7 Rekomendasi kegiatan yang mengikuti strategi portal siswa animasi SMK.

\begin{tabular}{|c|c|}
\hline \multirow{4}{*}{$\begin{array}{l}\text { Rekomendasi Kegiatan } \\
\text { Komposisi siswa dalam sebuah kelas dibuat } \\
\text { seimbang di tingkat awal sesuai perolehan } \\
\text { predikat yang didapatkan dari masing-masing } \\
\text { unsur gambar. }\end{array}$} & Manfaat \\
\hline & $\begin{array}{l}\text { Menyeimbangkan komposisi siswa } \\
\text { dengan predikat rendah dengan predikat } \\
\text { baik di masing-masing unsur gambar di } \\
\text { dalam kelas. }\end{array}$ \\
\hline & $\begin{array}{l}\text { Meminimalisir beda kemampuan yang } \\
\text { terlalu jauh dalam satu kelas }\end{array}$ \\
\hline & $\begin{array}{l}\text { Meniadakan pengistimewaan satu kelas } \\
\text { dengan kelas lainnya }\end{array}$ \\
\hline \multirow[t]{3}{*}{$\begin{array}{l}\text { Memperkuat unsur gambar yang rata-rata } \\
\text { berpredikat rendah dengan cara intensif dalam } \\
\text { penyelenggaraan akademik di tingkat awal. }\end{array}$} & $\begin{array}{l}\text { Meningkatkan kemampuan rata-rata } \\
\text { siswa yang memiliki predikat rendah } \\
\text { sesuai dengan unsur gambarnya. }\end{array}$ \\
\hline & $\begin{array}{l}\text { Penyeragaman kemampuan dasar siswa } \\
\text { di tingkat awal sehingga memudahkan } \\
\text { seluruh siswa untuk menerima materi di } \\
\text { tingkat berikutnya }\end{array}$ \\
\hline & $\begin{array}{l}\text { Memudahkan mencari kriteria pelatihan } \\
\text { dan recruitmen guru yang sesuai dengan } \\
\text { kebutuhan berdasarkan predikat tes. }\end{array}$ \\
\hline $\begin{array}{l}\text { Pengelompokan keahlian di tingkat akhir } \\
\text { berdasarkan hasil predikat tertinggi masing- } \\
\text { masing siswa. }\end{array}$ & $\begin{array}{l}\text { Spesialisasi kemampuan siswa dalam } \\
\text { melakukan kerjasama tim proyek } \\
\text { animasi sesuai dengan keahlian yang } \\
\text { menonjol pada masing-masing siswa. }\end{array}$ \\
\hline
\end{tabular}

\section{$5 \quad$ Kesimpulan}

Kondisi kompetensi edukasi animasi tingkat SMK Cimahi masih kurang dapat bersaing dan berkualitas dikarenakan kurangnya penguatan faktor-faktor dasar animasi seperti kemampuan menggambar dasar yang tidak pula didukung oleh pengajar dan sarana-prasarana yang tepat dan memadai. Hasil tes menunjukkan lemahnya kompetensi siswa animasi SMK Cimahi di ranah afeksi dan psikomotor yang berarti kurangnya daya ekspresif dan pengalaman gerak merancang animasi melalui penguasaan teknik-teknik keahlian animasi dasar.

Berdasarkan hasil analisa tes gambar tersebut disusunlah sebuah strategi pengembangan kompetensi yang dimulai dari seleksi awal pendidikan formal animasi yaitu berupa strategi portal kreatif sebagai saringan awal pendeteksian kemampuan dasar calon siswa animasi agar siswa yang masuk dalam jalur formal tersebut benar-benar tersaring dan terpetakan kemampuan dasarnya. 
Setelah seluruh aktifitas seleksi awal dengan optimal, maka selanjutnya dapat diupayakan aktivitas pendukung penunjang kompetensi siswa dari sisi non formal yang tidak terkait dengan kurikulum formal yang diantaranya adalah memberdayakan siswa untuk bergabung dan turut serta dalam sebuah klub, komunitas, dan atau suatu asosiasi animasi untuk mengasah daya saing mereka.

Sebagai penutup, dapat disusun sebuah bagan penyempurnaan pada Gambar 5 yang diadaptasi dari media kit Prospectus of Animation Program dari Jurusan Animasi SMKN 4 Malang [11] sebagai rangkuman bahan peningkatan kompetensi animasi yang dapat diterapkan di edukasi SMK animasi Cimahi.

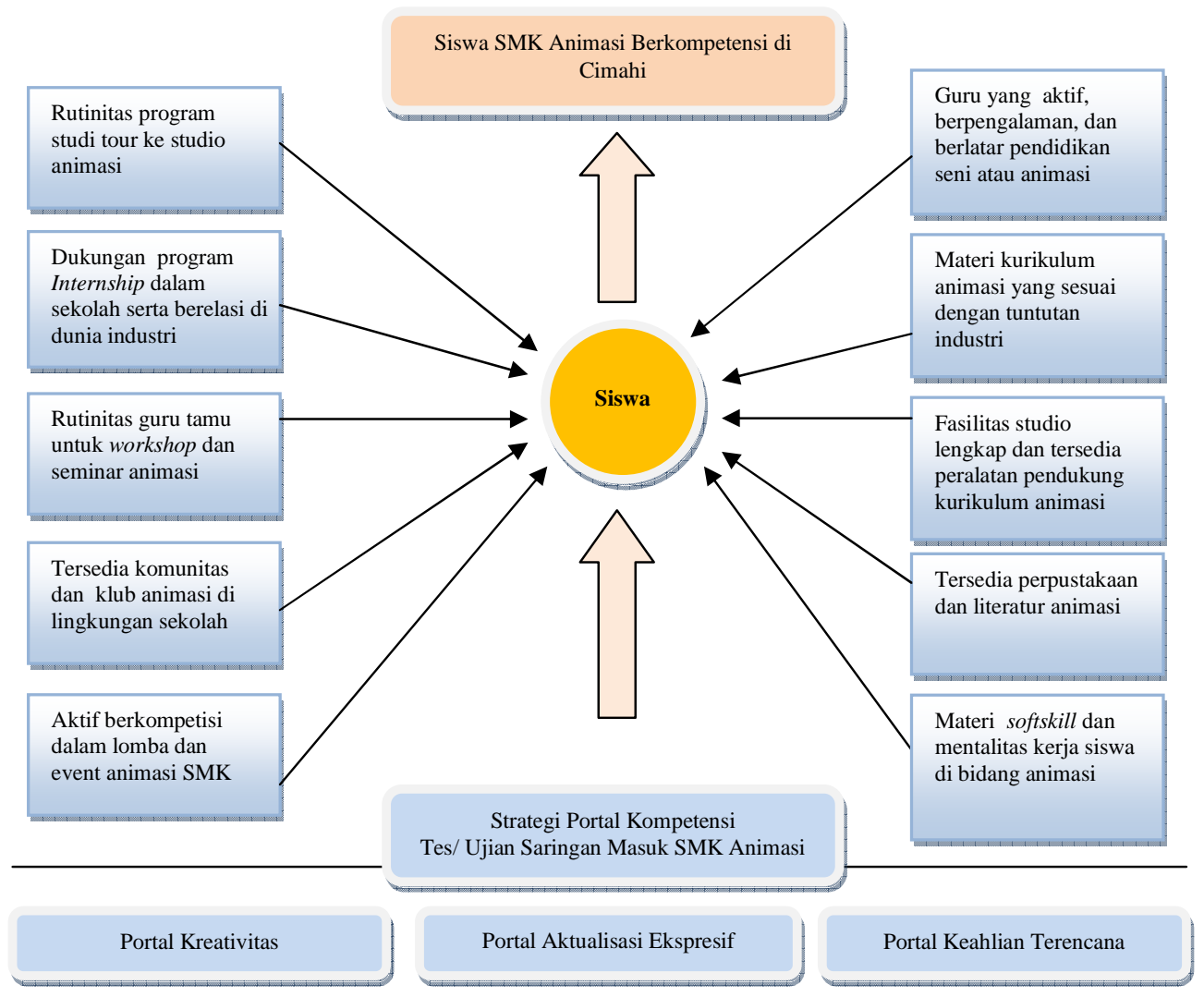

Gambar 5 Bagan penyempurnaan peningkatan kompetensi edukasi animasi tingkat SMK adaptasi dari media kit Prospectus of Animation Program SMKN 4 Malang. 


\section{Ucapan Terima Kasih}

Ucapan terima kasih kepada Pemerintah Kota Cimahi dan Cimahi Creative Association (CCA), rekan-rekan akademisi di SMKN 1 Cimahi, SMK-TI Garuda Nusantara Cimahi, SMKN 4 Malang, dan SMKN 14 Bandung serta Tanoto Foundation dengan dukungan beasiswa studinya.

\section{Referensi}

[1] Cimahi Jadi Basis Industri Animasi, diakses dari, http://finance.detik. com/read/2008/12/23/104403/1058191/480/ cimahi-jadi-basis-industrianimasi??topnews. (14 Mei 2010)

[2] Standar Kompetensi Nasional Bidang Keahlian Animasi, diakses dari, http://tutorial.smkn6dki.or.id/index.php?action=downloadfile $\&$ filename $=$ skn $\% 20$ final $\% 20$ rev $\% 200206$.doc \&directory=public_downlo ads/SKNI_Animasi\&PHPSESSID=b00890a6f28676a538f88c27c0aab52. (20 Mei 2010)

[3] Munthe, B. 2009. Desain Pembelajaran, Yogyakarta, PT. Pustaka Insan Madani.

[4] Peraturan Pemerintah Republik Indonesia Nomor 19 Tahun 2005 Tentang Standar Nasional Pendidikan.

[5] Badan Standar Nasional Pendidikan. 2006. Panduan Penyusunan Kurikulum Tingkat Satuan Pendidikan Jenjang Pendidikan Dasar dan Menengah.

[6] Departemen Pendidikan Nasional. 2007. Naskah Akademik Kajian Kebijakan Kurikulum SMK, Jakarta, Pusat Kurikulum Badan Penelitian dan Pengembangan Departemen Pendidikan Nasional.

[7] Jesstaylor. 2010. Pencil Drawing Techniques, http://www.elfwood.com/ farp/ theart/jesspencil/jesspencil2.html (25 Mei 2010).

[8] Primadi, T. 2000. Proses Kreasi, Apresiasi, Belajar, Bandung, Penerbit ITB.

[9] Bloom, B.S., Engelhart, M.D., Furst, E.J., Hill, W.H. \& Krathwohl, D.R. 1956. Taxonomy of Educational Objectives: The Classification of Educational Goals; Handbook I: Cognitive Domain, New York, Longmans, Green.

[10] Arikunto, S. 1998. Prosedur Penelitian Suatu Pendekatan Praktek, Jakarta, PT. Rineka Cipta.

[11] Media Kit Jurusan Animasi SMKN 4 Malang. 2007. Prospectus of Animation Program, Malang, SMKN 4 Malang. 